\title{
Journal of Coloproctology
}

\author{
www.jcol.org.br
}

\section{Editorial}

\section{Daher Cutait Daher Cutait}

I start this text exactly on the day of the centennial of Professor Daher Cutait - September 28, 2013, with the emotional feelings that this day brings to me, but with the serenity of one who lived with the father, the man and the professional.

Daher was a determined man, who overcame his obstacles with dedication, honesty and, above all, the realization that he lived to fulfill a mission. I believe these qualities he inherited from his parents, Elias and Eugenia. Elias was only 13 years old when he left his family, who lived in a small village in southern Lebanon, crossed the desert and boarded a ship bound for Brazil, to "make America" as it was so called then. Determined and dedicated, he managed to have his own business at the age of twenty-something, and, as everyone did back then, returned to Lebanon to marry. There he met Eugene, from a traditional family from Beirut, one of the rare women with a university degree at the time, who had the characteristic of being ahead of her time. Elias, despite the limitations of his schooling, was cultured and charming enough to attract her. They moved to Brazil after having two children - Daher became the first of the next five children to be born in our country - having decided that Brazil would be their country, to the point that my grandfather practically stopped talking Arabic at home, only Portuguese.

At the moment when he had to decide which path to take, Daher sought advice from his mother, who expressed her desire to see him become a doctor, since the successive generations always had a doctor in the family. Daher liked the idea and joined the School of Medicine of the University of Sao Paulo, where he graduated in 1939. During medical school, he was an esteemed colleague, as reported by some of his contemporaries whom I had the opportunity to meet. His great love for soccer and his qualities as a player led him to compete for his school and to play in an amateur team, which he had to quit when he became a physician, the São Paulo Futebol Clube, the team of his heart (and mine too!).

In his final year of medical school he chose surgery, influenced by the austere and competent figure of Professor Benedito Montenegro, and being a restless spirit, he decided in 1941 to study in the United States where he attended the benchmark centers of the time, such as the Massachusetts General Hospital, the Lahey Clinic and the Presbyterian Hospital. However, the year-long period as a resident at the University of Michigan Hospital, under the guidance of Dr. Frederick Coller one of the great American references in colorectal surgery of the time, a still incipient area of work, was crucial for his life.

With international experience and a defined specialty, he returned to Brazil in 1943, thinking of his sick father, and somewhat fearful of being sent to a war that was not his. Soon he joined the Department of Surgery of the School of Medicine, at USP, of which Dr. Montenegro, his mentor, was the leader. When Hospital das Clinicas was opened in 1944, it was he who was on duty in the ER and had the privilege of performing the first surgery at the hospital, a case of acute appendicitis. In 1947 he was appointed chief of Coloproctology, a position he held until his retirement in 1983 as adjunct professor.

A dedicated surgeon, he was a great teacher not only for his expertise, but because he was concerned about the learning as well as the scientific and professional growth of those around him. Socially speaking, this involvement was so intense that he spent much of his free time with physicians. I have recollections of him receiving colleagues, trainees and visitors from abroad at the infallible Saturday lunches that included the "feijoada" that my mother always prepared for an undefined number of guests, I remember as well the nights and weekends on which I would see him reviewing theses and scientific works. Even today, many physicians whom I meet at conferences or in hospitals, here and abroad, have something to tell me about "how Dr. Daher helped or influenced me." What a privilege!

With more than 120 published scientific papers, 40 book chapters, hundreds of topics presented at national and international conferences, hundreds of lectures at workshops and conferences in the country and abroad, he established not only a solid personal reputation, he was of great importance to help Coloproctology become a specialty in Brazil. and

\footnotetext{
${ }^{*}$ Corresponding author.

E-mail: rcutait@uol.com.br (R. Cutait) 
became an important link between Brazilian, Latin American, American and European specialists. As a matter of fact, one of his most prized titles was that of the "Father of Latin-American Coloproctology", awarded to him by ALACP. His lowering technique for megacolon and rectal cancer has gained worldwide fame and has a story worth telling.

In 1960, during the 1st ALACP Conference held in São Paulo, he was talking to Rupert Turnbull, from the Cleveland Clinic, at a dinner party held in his house, during which at some point he went on to describe a technique he had developed for rectal cancer. Daher immediately went to his study and brought out the drawings of his technique and they both laughed to find that, without knowing each other personally and having never spoken about it, they had had the same idea! The fact is that Daher published his work, along with Felipe Figliolini in Diseases, a few months before Turnbull published his own work in the Cleveland Clinic journal.

Daher Cutait also found time to dedicate to his community. And so, he was the president of the Brazilian Society of Coloproctology (1957 and 1986), one of the founders of the Latin American Association of Coloproctology and its first president (1957-1960), he also was president of the Brazilian College of Surgeons (1976-1979), the Latin American Federation of Surgery (1977-1982) and the International Society of University Colon and Rectal Surgeons (1985-1986). He presided conferences for all these societies as well as for the World Congress of Coloproctology in 1986. But Daher also found time to dedicate to the Hospital Sírio Libanês, being its first Clinical Director from 1965 until his death in 2001, where in fact he also was the institution's president, helping it to grow and gain prestige as a center of excellence and reference. To this hospital he imprinted his humanistic spirit and constant pursuit for the highest quality. His view of the doctors at the institution was very clear: to make them a priority and to give them the best working conditions, since this was the best way to care for the patients treated at the institution. Finally, Daher did not neglect his private practice, having been one of the most respected and sought-after surgeons of his time.

I think Daher Cutait achieved in his profession everything that anyone could aspire to be : he was an excellent surgeon, recognized not only by his peers but also by his patients, who were his top priority, above his personal or momentary needs; he was esteemed and respected; he developed a surgical technique that bears his name and that marked the history of colorectal surgery; he was a great professor and teacher of many generations; he published good scientific work; he devotedly advised many surgeons and teachers directly or indirectly; he was an active member of national and international medical societies; he raised a beautiful family and, above all, he had a very happy life!

I can't finish this text without mentioning that Daher had an angel in his life, my mother Yvonne, who always tried to understand him and help him in his mission, often assuming the role of father and mother for us, her four children. I can say that my siblings and I, following his constant example, grew up guided by the qualities he exercised in his life: honesty, dedication to causes, respect for human beings. His faults? Yes, he had them, but they did not obscure, or diminish his positive impact on us.

Daher Cutait time on earth ended, but he is still among us, through his example and accomplishments.

Raul Cutait

Departament of Surgery, School of Medicine, Universidade de São Paulo (USP)

Academia Nacional de Medicina Sociedade Brasileira de Coloproctologia 